論文・Paper

\title{
リターナブルびんの送びん工程における加傷について
}

\author{
横倉修一・岡田稔* \\ $\left(\begin{array}{ll}\text { 麒麟麦酒（株） } & \text { 富田製壜工場 } \\ * \text { 麒麟麦酒（株），製造部 }\end{array}\right)$
}

飲料びんが充てん工場の送びん工程で受ける加傷について, 実験用送びんコンベアを用いて検討 を行った．試料びんとしてはリターナブルびん（重量 $605 \mathrm{~g}$ ）を用い，所定長さのコンベア上を繰 り返し送びんを行い,びん外表面の加傷(すり傷及び当たり傷)の発生度合いについて検討を行った. またその際の発生音について周波数分析並びに音圧レベルの測定を行い, 送びんスピードとの関係 についても併せて検討を行った。 その結果以下のような知見が得られた.

（1）すり傷の発生についてみる之, 同一加傷度の場合には送びんスピードと送びん距離の間に 両対数で負の直線関係が認められた。

（2）当たり傷についてみると, 当たり傷（小）(Herztion cone の長径が $1.5 \mathrm{~mm}$ 以下）が発生 する限界衝撃エネルギーは 0.3 Joule 程度であることが分った。この值から当たり傷が発生しない ための適正送びんスピードをびん重量との関係において理論的に算出し得た.

（３）送びんスピードと発生音の音圧レベルの間には直線関係が認められた。したがって音圧レ ベルを測定することにより，間接的にびんの加傷度を推定し得ると考えられる。

(1984 年1月 19 日受付)

\section{Abrasion of Returnable Bottles during Transportation on Bottle Conveyors}

\author{
Shuichi YOKOKURA and Minoru OKADA* \\ $\left(\begin{array}{l}\text { Tonda Bottle-Manufacturing Plant, Kirin Brewery Co., Ltd. } \\ \text { 4473-4, Ooaza Tonda, Shinnanyo-shi, Yamaguchi } 746 \\ \text { * Production and Technical Control Department, Kirin Brewery Co., Ltd. }\end{array}\right)$
}

Abrasion of returnable bottles during transportation on conveyors in a bottling hall was investigated, using conveyors for experimental use. Using test bottles, the weight of which is ca. $605 \mathrm{~g}$, the experiments were carried out, by running them on these conveyors repeatedly at a certain speed, and the grade of abrasion on their outer surface was quantitatively investigated. At the same time, frequency analysis and sound pressure level of noise generated were also investigated from the accoustic standpoint. Finally, the relationship between abrasion grade, sound pressure level and running speed of bottles was investigated. The results obtained are summarized as follows:

(1) In the case of leight abrasion (scuffing), a linear relationship was obtained between running speed and the distance of transportation in logarithmical unit at a same abrasion grade level.

(2) In the cases of heavy abrasion (Herztian crack), the diameter of which is under $1.5 \mathrm{~mm}$, impact energy of lower limit was found to be ca. 0.3 Joule.

( 3 ) A linear relationship was obtained between running speed and sound pressure level.

[Received January 19, 1984]

Key-words : Bottle, Abrasion, Scuffing, Herztian crack, Impact energy, Frequency analysis, Sound pressure level

1. 緒言

リターナブル（回収，再使用可能）の飲料びんはアル
カリ洗净，充てん工程，並びに市場での流通工程を繰り

返す過程で，びん外表面は加傷し，その結果，すり傷の 
発生による包装美観の低下，並びに当たり傷の発生によ るびん強度の劣化を引き起こすことは周知のとおりであ $ろ^{11,2)}$.

ところで飲料びんの取り扱いについては，近年世界的 にみてプラスチック製クレートの普及により，流通工程 での加傷の機会は著しく減少したが，一方充てん工程に おいては，充てんスピードの高速化が進み，加傷が促進 される傾向にすらあり，したがって加傷の大半は充てん 工程（なかんずく送びんコンベア上）に集中しているの が現状である.

そこで本研究は，試料びんとして我が国で広く使用さ れているびん種の一つを選び，実験用送びんコンベア上 を繰り返し送びんを行い，びん外表面の加傷についてす り傷並びに当たり傷の発生を，送びんスピードとの関係 において検討を行った。

ところで送びん工程で発生する音はびん同士の衝突， こすれ合いなどに起因するものであり，したがってその 音圧レベルは衝撃エネルギーを間接的に表していると考 えられる ${ }^{3)-6)}$. そこでこの発生音に注目して，周波数分 析，音圧レベルなどの測定を行い，送びん条件，びん加 傷度との関係について併せて検討を行った。

\section{2. 実験条件}

\section{1 試料びんの概要}

\section{（i）加傷実験に用いた試料びん}

試料びんは従来より我が国で広く使用されているびん 種の一つであり，その諸元は以下のとおりである．重量 $605 \mathrm{~g}$, 胴径 (円筒部) $75 \mathrm{~mm}$, 内容量 $658 \mathrm{ml}$, 肉厚約 $4 \mathrm{~mm}$.

なおこの試料びんは円筒下部（底から約 $15 \mathrm{~mm}$ 高さ の位置）並びに円筒上部（びん底より約 $140 \mathrm{~mm}$ 高さの 位置）で管径が $0.1 \sim 0.2 \mathrm{~mm}$ 程度他の管径より大きく なっているため，この二つの位置を中心に表面傷が集中 する傾向にあり，したがって加傷度の測定はこれら゙の位 置を中心に行った.

\section{2 実験用送びんコンベアの概要並びに送びん条件} 本研究においては図 1 及び図 2 に示すような 2 種類の コンベア (コンベア $(\mathrm{A})$ 及びコンベア $(\mathrm{B})$ ) を用いた.

\section{(i ) コンベア (A)}

このコンベアは図 1 に示すように, 単列（ガイド幅, 約 $85 \mathrm{~mm}$ ) で全長 $24.5 \mathrm{~m}$ のループ状であり, 送びん過 程でびんにライン圧力（びん同士の押し合い力）を発生 させるために，約 $3^{\circ}$ の傾斜をもたせている．このコン ベア上に試料びんを 320 本単列状に並べて, 送びんス ピード $5 \sim 40 \mathrm{~m} / \mathrm{min}$ の範囲にわたって，送びんを行っ た。なお送びん時はびん底とコンベアのトップ・プレー ト (ステンレス製) 間の摩擦抵抗を緩和させるために, 脂肪酸エステル系の潤滑剤をプレート上に滴下した. 試料びんの加傷実験は空びん状態並びに水を満量充て

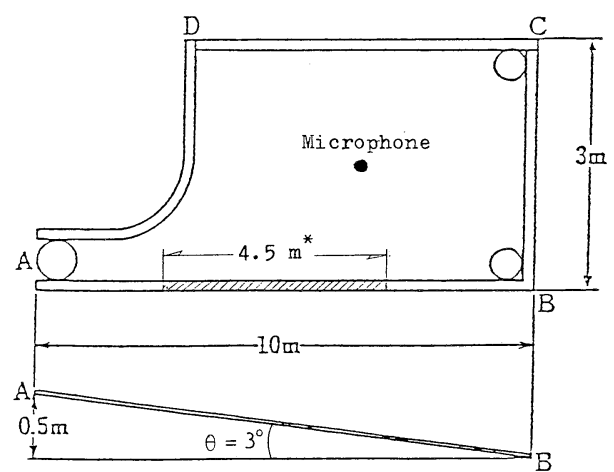

Fig. 1. Schematic illustration of a test conveyor (A). * Distance of bottle transportation.

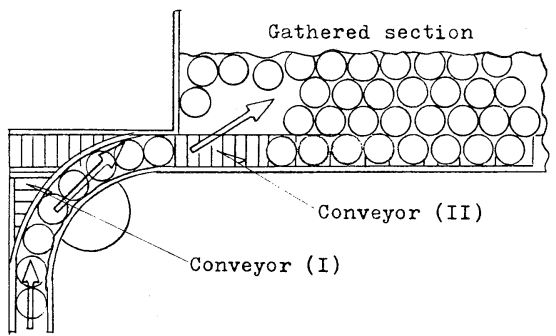

Fig. 2. Schematic illustration of a test conveyor (B). Test bottles $(n=15)$.

んした状態（味入り状態と呼ぶことにする）のそれぞれ について，コンベア上の直線区間の $4.5 \mathrm{~m}$ (送びん距離) を所定回数，繰り返し送びんを行った。なお送びん実験 時に試料びんに加わるライン圧力は約 $3 \mathrm{~kg}$ に調整した。 またコンベア速度と送びん速度の関係はスリップ率（コ ンベア速度/送びん速度）として表示した（図 4 及び図 5 の ( 1 ), ( 2 ) 参照).

\section{(ii ) コンベア (B)}

このコンベアは図 2 に示すように, 単列コンベア ( I ), (II ), 及び集びん部から構成されており, 試料びん（15 本）はまずコンベア（Ｉ）を出発して，コンベア（II） に移り，最終的に集びん部において静止している試料び ん群に衝突して止まる.この操作を所定回数, 繰り返し て試料びんを加傷した。なおコンベア（Ｉ）及び（II） の速度は等しくした。

\section{3 発生音の測定}

送びん時の発生音について周波数分析を行い，びんの 共振周波数を測定する場合は周波数分析計(リオン社製, SA-35 型) を用いた。 またオクターブ分析を行う場合 はオクターブ騒音分析計（リオン社製，NA-13型）を 用いた。

測定時の吸音マイクの位置については，コンベア $(\mathrm{A})$ ではループの中心点 (図 1 参照)，コンベア (B) では 集びん部の先端側より $0.5 \mathrm{~m}$ 離れた位置とし，いずれ も床上 $1.5 \mathrm{~m}$ 高さとした.なお音圧レベルは $\mathrm{A}$ 特性 (All 
pass $)^{7)}$ 並びに共振周波数において測定し, いずれも暗 騒音補正を行った.

\section{4 加傷度の測定方法}

試料びんの加傷は大まかに，すり傷，当たり傷（小） 及び当たり傷（大）の 3 段階に分類されるが，それぞれ について以下のような方法で測定した.

\section{（i）すり傷}

主としてびん同士の押し合い，擦れ合いなどによりび ん外表面にすり傷が発生して白化現象 ${ }^{11,2)}$ を呈するもの で, 肉眼観察ではクラックの発生までに至らない程度の 加傷であり, 加傷度は肉眼観察による標準加傷びんとの 比較という方法で測定を行った。

\section{（ii）当たり傷}

主としてびん同士の衝突により発生する加傷であり, 肉眼観察によりコーン状のクラック (Hertzian crack) ${ }^{8) \sim 11)}$ の発生が認められ, コーンの大きさが長径 $1.5 \mathrm{~mm}$ 以下 を当たり傷 (小), $1.5 \mathrm{~mm}$ 以上を当たり傷（大）に区 分し, それぞれの発生数/本をもって加傷度の指標とし た。

\section{3. 実験結果並びに考察}

\section{1 送びん条件と音圧レベルの関係}

\section{（i）コンベアAの場合}

試料びんを用いて送びん実験を行い，発生音の音圧レ ベル (A 特性, phon) 並びに共振周波数での音圧レベ ル $(\mathrm{dB})$ について測定した。

まず空びん状態についての周波数分析結果を図 3 に示 す.図 3 から明らかなように共振周波数は約 $3300 \mathrm{~Hz}$ に あることが分った。 またコンベア速度と発生音の音圧レ ベルの関係をみると，図４から明らかなように送びんス ピード, 約 $10 \mathrm{~m} / \mathrm{min}$ 以上では, A 特性 (phon) 及び共 振周波数 $(3300 \mathrm{~Hz})$ での音圧レベルと送びんスピード の間にはそれぞれ直線関係が認められており，これら二
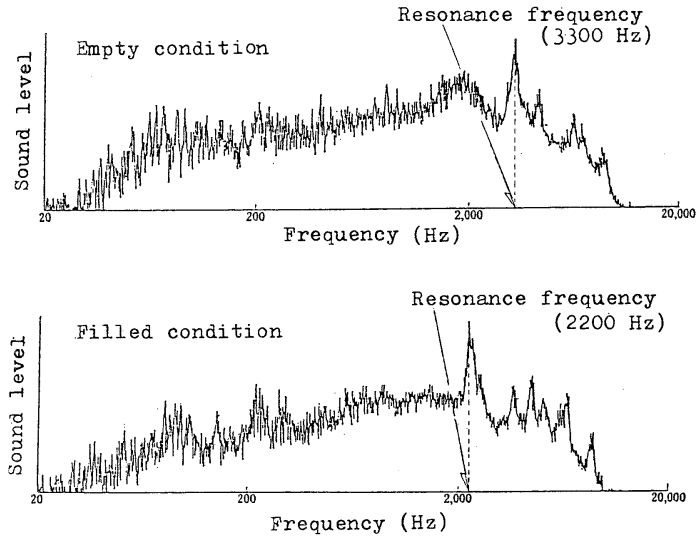

Fig. 3. Frequency analysis of sound generated from test bottles ( I ).
つの直線こう配はほぼ同程度であった. またこの場合送 びんスピード約 $10 \mathrm{~m} / \mathrm{min}$ 以下で直線関係が得られな かった原因としては，音圧レベルの低下とともに暗騒音

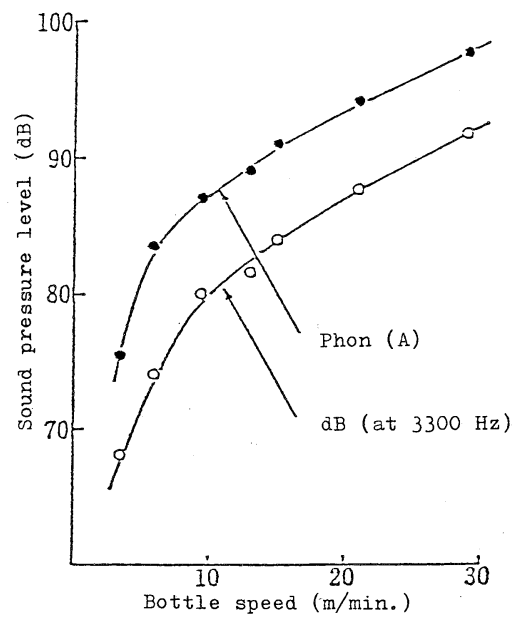

Fig. 4. Relationship between bottle speed and sound pressure level at the conveyor (A).

(1)

\begin{tabular}{|c||c|c|c|c|c|c|c|}
\hline $\begin{array}{c}\text { Conveyor speed } \\
(\mathrm{m} / \mathrm{min})\end{array}$ & 5 & 10 & 15 & 19 & 22 & 30 & 40 \\
\cline { 2 - 7 } & 3.5 & 6.2 & 9.6 & 13.3 & 15.0 & 21.0 & 29.0 \\
\hline $\begin{array}{c}\text { Bottle speed } \\
(\mathrm{m} / \mathrm{min})\end{array}$ & 1.4 & 1.6 & 1.5 & 1.4 & 1.5 & 1.4 & 1.4 \\
\hline Slip rate & &
\end{tabular}

(2) At an empty condition of test bottles.

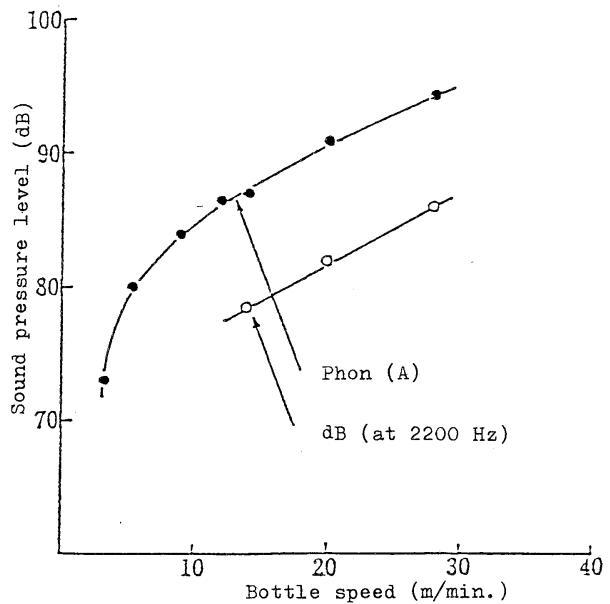

Fig. 5. Relationship between bottle speed and sound pressure level at the conveyor (A).

(1)

\begin{tabular}{|c||c|c|c|c|c|c|c|}
\hline $\begin{array}{c}\text { Conveyor speed } \\
(\mathrm{m} / \mathrm{min})\end{array}$ & 5 & 10 & 15 & 19 & 22 & 30 & 40 \\
\hline $\begin{array}{c}\text { Bottle speed } \\
(\mathrm{m} / \mathrm{min})\end{array}$ & 3.3 & 5.8 & 9.0 & 12.0 & 14.0 & 20.1 & 28.1 \\
\hline Slip rate & 1.5 & 1.7 & 1.6 & 1.6 & 1.6 & 1.5 & 1.4 \\
\hline
\end{tabular}

(2) At a filled condition of test bottles. 
の影響が顕在化してくるためと考えられる.

次に味入り状態の場合について検討を行った。発生音 の周波数分析結果を図 3 に示す。図 3 から明らかなよう に共振周波数は約 $2200 \mathrm{~Hz}$ であることが分った. また図 5 より明らかなように, 同じく送びんスピード，約 10 $\mathrm{m} / \mathrm{min}$ 以上の領域では音圧レベルとの間に直線関係が 認められた。

以上の結果から明らかなように, 発生音の音圧レベル が既知であれば，送びんスピードを推定し得るわけであ る。また同一送びんスピードにおいて空びん状態の方が 味入り状態よりも音圧レベルが高い原因としては，味入 り状態においては音響エネルギーの一部が内容液 (水) に吸収されるためと考えられる.

\section{（ii） コンベア（B）の場合}

同じく試料びんを用いて送びん実験を行い, 発生音の 音圧レベル ( $\mathrm{A}$ 特性) を測定した. その結果を図 6 に 示す。図 6 から明らかなように空びん状態，味入り状態 ともに送びんスピードと発生音の音圧レベルの間には直 線関係が認められた。

ところでコンベア (B) では試料びん 15 本を静止状 態のびん群に衝突させた場合の衝撃音であり, 音圧レベ ル並びに直線こう配（送びんスピードと音圧レベルの関 係）において，コンベア (A) の場合に比べてかなり高 いことが分った。

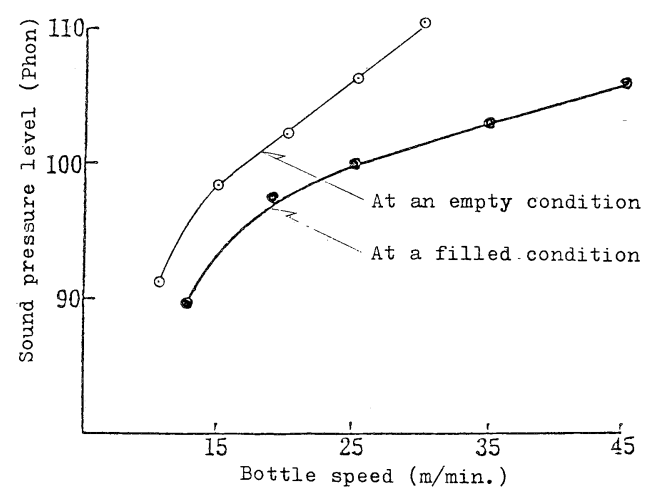

Fig.6. Relationship between bottle speed and sound pressure level at the conveyor (B).

\section{2 送びんスピードとびん加傷度の関係}

\subsection{1 コンベア (A) の場合}

\section{（）空びんの場合}

まず送びんスピードと加傷度 (すり傷) の関係につい て検討を行った。 その結果を図7に示す。図 7 から明ら かなように送びんスピード（10〜 $40 \mathrm{~m} / \mathrm{min}$ の範囲）と 送びん回数の間には両対数プロットでほぼ直線関係が認 められた。なお送びんスピードと発生音の音圧レベルの 間には直線関係があるから，音圧レベルを指標としてび ん加傷度 (すり傷) を間接的に定量し得ると考えてよい。

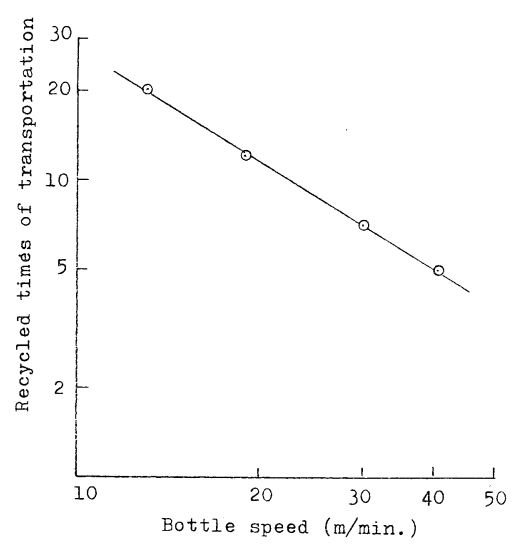

Fig. 7. Relationship between bottle speed and recycled times of transportation at the same abrasion grade (scuffing). At the conveyor (A).

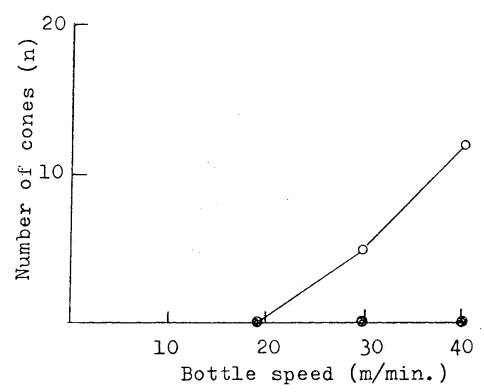

Fig. 8. Relationship between bottle speed and generated Hertzian cones per bottle.

(1) $\bigcirc-\bigcirc$ : Diameter $(<1.5 \mathrm{~mm})$

: Diameter $(>1.5 \mathrm{~mm})$

(2) At an empty condition (conveyor (A))

次に送びんスピードと加傷度 (当たり傷) の関係につ いて検討を行った。 その結果を図 8 に示す。図 8 から明 らかなように，まず当たり傷（小）は送びんスピード約 $30 \mathrm{~m} / \mathrm{min}$ から発生し始め, 一方当たり傷（大）は40 $\mathrm{m} / \mathrm{min}$ でも全く発生しなかった.

ところで当たり傷の場合を考えると，送びんスピード の上昇とともにびんとコンベア・ガイドの接触摩擦力は 大きくなり，その結果コンベア上でのびんの回転速度が 急激に上昇して, びん同士の擦机合いが漸次衝撃的なも のに変わっていき，当たり傷が発生するに至ると考えら れる。

\section{（ii）味入りびんの場合}

当たり傷を中心として送びんスピードと加傷度の関係 について検討を行った，その結果を図 9 に示す。図 9 か ら明らかなように，まず当たり傷（小）の発生数は送び んスピードの上昇とともにほぼ直線的に増加した。一方

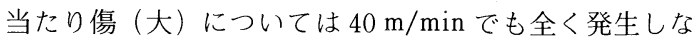
かった。 


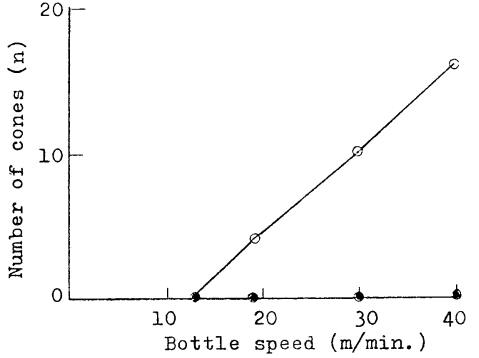

Fig. 9. Relationship betwee bottle speed and generated Herztian cones per bottle.

( 1 ) $\bigcirc-\bigcirc$ : Diameter $(<1.5 \mathrm{~mm})$

: Diameter $(>1.5 \mathrm{~mm})$

(2) At a filled condition (conveyor (A))

以上の結果から，味入り状態において当たり傷（小） が発生し始める送びんスピードは空びん状態の場合より も約 $10 \mathrm{~m} / \mathrm{min}$ 低く，この原因としては水の充てんによ るびん重量の増加によるものと考えられる.

\subsection{2 コンベア（B）の場合}

コンベア (B) の場合はびん同士の衝突による加傷が 中心となるため，当たり傷を中心に検討を行った．まず 空びん状態の場合についてみると，図 10 から明らかな ように当たり傷（小）では約 $20 \mathrm{~m} / \mathrm{min}$ ，当たり傷（大） では $35 \mathrm{~m} / \mathrm{min}$ から加傷が始まり, 送びんスピードの上 昇とともに加傷度はほぼ直線的に増加した。

次に味入り状態についての結果を図 11 に示す. 図 11 から明らかなように当たり傷（小）では送びんスピード 約 $13 \mathrm{~m} / \mathrm{min}$, 当たり傷. (大) では約 $25 \mathrm{~m} / \mathrm{min}$ で加傷 が始まった。

以上の結果から明らかなように，コンベア (B) にお ける当たり傷 (小) の発生開始時の送びんスピードはコ ンベア (A) の場合に比べて約 $10 \mathrm{~m} / \mathrm{min}$ 程度低いこと が分った.この原因としては，コンベア (B) の場合は

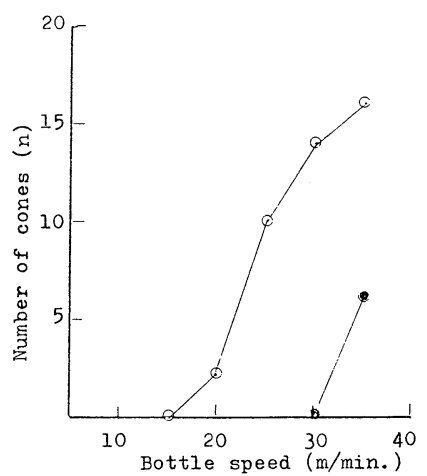

Fig. 10. Relationship between bottle speed and generated Herztian cones per bottle.

(1)

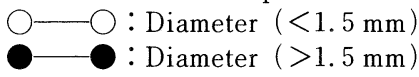

(2) At an empty condition (conveyor (B))

( 3 ) Recycled times of transportation : 20

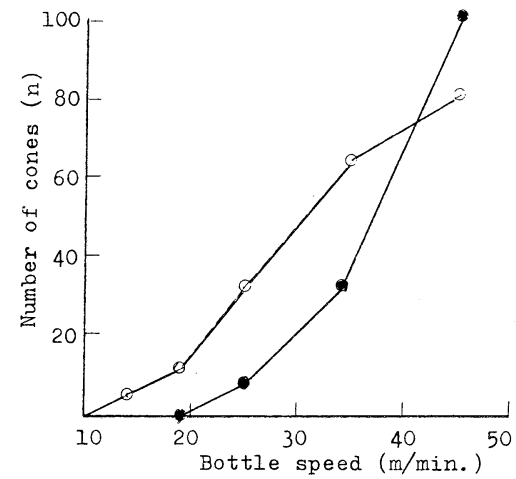

Fig. 11. Relationship between bottle speed and generated Herzian cones per bottle.

( 1 ) $\bigcirc-\bigcirc:$ Diameter $(<1.5 \mathrm{~mm})$

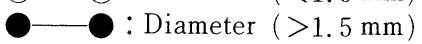

(2) At a filled condition (conveyor (B))

( 3 ) Recycled times of transportation : 20

びん同士の直接的な衝突による加傷であり，一方コンベ ア (A) においては主としてびん同士の擦れ合いによる 加傷亡考えられ，加傷のされ方が異なるためと考えられ る.

\section{3 衝撃エネルギーと加傷度の関係}

送びん工程におけるびんの加傷は大まかに以下の二つ の場合が考えられる ${ }^{12)}$.

（）びんがコンベア上で連続的に流れる場合であ り，びん同士の押し合い，擦れ合いなどにより加傷する ものであり，コンベア (A) の場合に対応する.

（ii） コンベア上でびん同士の衝突により加傷する場 合であり，コンベア (B) の場合に対応する.

いま上記（ii ）の場合についてびん衝撃時の衝撃エネ ルギーと加傷度 (当たり傷) の関係について検討してみ る. まず送びん速度， $v$ で流れているびん（質量： $m$ ) が静止しているびん群にぶつかって静止する場合を考え ると，びんが受ける衝撃エネルギー，W は以下のよう に示される。

$$
W=\frac{1}{2} m \cdot v^{2}
$$

ところで本実験においては表 1 から, 当たり傷 (小) が発生する限界送びんスピードは約 $20 \mathrm{~m} / \mathrm{min}$, 当たり 傷（大）で $35 \mathrm{~m} / \mathrm{min}$ であり，これらの值から衝撃工ネ ルギーが求まり, 表 1 から当たり傷が発生し始める限界 衝撃エネルギー $W$ は当たり傷（小）で約 $0.29 \sim 0.34$ Joule, 当たり傷（大）では 1.0〜1.1 Joule 程度である ことが分った。

したがってびん当たり傷を発生させずにコンベア上を 送びんさせるための適正スピード， $v$ は，使用するびん 重量が分れば，本実験により得られた限界衝撃エネル ギ一值（表 1 参照）を用いて，（1）式から容易に求め 
Table 1. Limited bottle speed and impact energy at the generation of Herztian cones.

\begin{tabular}{|c|c|c|c|}
\hline & \multirow{2}{*}{$\begin{array}{l}\text { Value of } \\
\text { lower limit }\end{array}$} & \multicolumn{2}{|c|}{ Diameter of cones } \\
\hline & & $<1.5 \mathrm{~m} / \mathrm{m}$ & $>1.5 \mathrm{~m} / \mathrm{m}$ \\
\hline \multirow{2}{*}{$\begin{array}{l}\text { Empty } \\
\text { condition }\end{array}$} & Bottle speed & $20 \mathrm{~m} / \mathrm{min}$ & $35 \mathrm{~m} / \mathrm{min}$. \\
\hline & Impact energy & 0.3 Joule & $1.0 \mathrm{Joule}$ \\
\hline \multirow{2}{*}{$\begin{array}{l}\text { Filled } \\
\text { condition }\end{array}$} & Bottle speed & $13 \mathrm{~m} / \mathrm{min}$. & $25 \mathrm{~m} / \mathrm{min}$. \\
\hline & Impact energy & 0.3 joule & 1.1 Joule \\
\hline
\end{tabular}

Note: 1) Test bottle: empty weight, $605 \mathrm{~g}$; 2) At the conveyor (B).

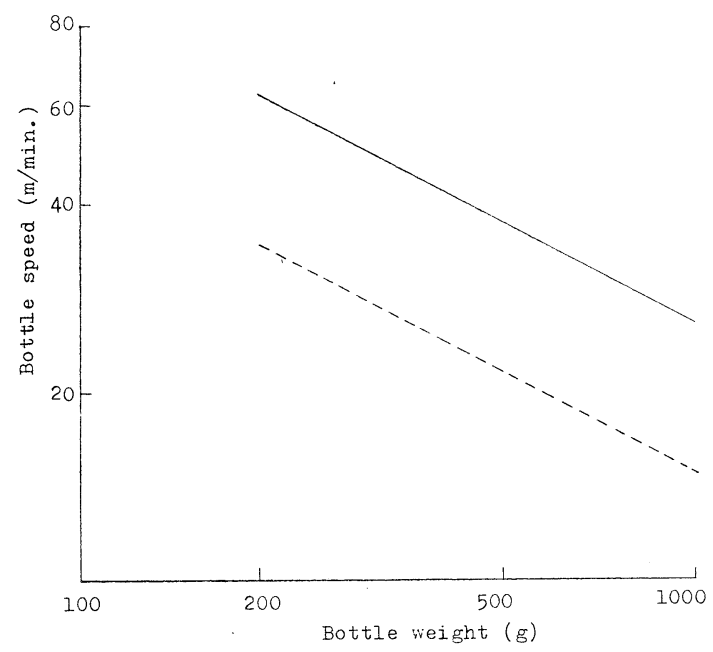

Fig. 12. Relationship between bottle weight and limited bottle speed at the conveyor (B).

(1) $\cdots$ : Diameter of cones $(<1.5 \mathrm{~mm})$

- Diameter of cones $(>1.5 \mathrm{~mm})$

(2) At an empty condition

られ，図 12 に示すような関係が理論的に成立する.し たがって適正送びんスピードはびん重量の増加ととも に，低下させていく必要のあることが分る.

以上の結果から明らかなように, 送びんスピードは送 びん条件に応じて慎重に決定され标ばならず, 特にコン ベア（B）のようにびんに衝撃的荷重が加わる工程にお いては，使用するびん種（特にびん重量）に応じて適正 な送びんスピードを選ぶことが，びんの耐用年数を延ば
すことにつながると考えられる。

\section{4. 総括}

飲料びんの送びん工程における加傷について，送びん スピードとの関係を中心とした検討を行った。試料びん としてはリターナブルびん（重量 $605 \mathrm{~g}$, 内容量 $658 \mathrm{ml}$ ) を用い，送びんスピード $10 〜 40 \mathrm{~m} / \mathrm{min}$ の範囲にわたり， 所定長さのコンベア上を繰り返し送びんを行い，びん外 表面の加傷（すり傷及び当たり傷）の発生度合いについ て測定するとともに，送びん時の発生音について周波数 分析並びに音圧レベルの測定を併せて行い，同じく送び んスピードとの関係について検討を行った. その結果以 下のような知見が得られた。

（1）すり傷 (Scuffing) の発生について，びんを連 続的にコンベア上を流した場合をみると，加傷度が同程 度の場合では送びんスピードと送行距離の間に両対数で 負の直線関係が認められた。

（2）当たり傷 (Hertzian core）の発生について, コンベア上でびん同士の衝突により肉眼で容易に観察し 得る程度の当たり傷（長径 $1.5 \mathrm{~mm}$ 程度）が発生し始め る限界衝撃エネルギ一は 0.3 Joule 程度と推定された。

（3）送びんスピードと発生音の音圧レベルの間には 直線関係が認められた。したがって音圧レベルが分れば, 送びんスピード並びに加傷状態を推定し得ることにな る.

\section{文献}

1) N. A. Hurt, R. Wallington and L.H. Myles, The Industrial Chemist, 581-84 (1953).

2) B. E. Moody, J. Soc. Dairy Technol., 12, 15-26 (1959).

3) S. Radandt, Brauwelt, 112, 1195-202 (1972).

4) S. Radandt, Brauwelt, 113, 1599-606 (1973).

5) F. Berg, Brauwelt, 113, 1759-63 (1973).

6) F. Berg and S. Radandt, Brauwissenschaft, 28, 224-27 (1975).

7) JIS-Z 8731.

8) Y.M. Tsai and H. Kolsky, J. Mech. Phys. Solids, 15, 263-78 (1967).

9) G. Schönbrunn, Glastechn. Ber.; 49, 103-13 (1976).

10) H.P. Kirchner and R. M. Gruver, Material Science and Engineering, 28, 153-60 (1977).

11） R. W. Davidge, 鈴木弘茂, 井関孝善訳, “セラミックの 強度と破壊”, 共立出版 (1967) p. 263-78.

12) J. Draebel, American Brewer, 29-48 (1960). 